\title{
Insulin-like Growth Factor I Binding in Hepatocytes from Human Liver, Human Hepatoma, and Normal, Regenerating, and Fetal Rat Liver
}

\author{
Jose F. Caro, John Poulos, Olivia Ittoop, Walter J. Pories, Edward G. Flickinger, and Madhur K. Sinha \\ Departments of Medicine, Section of Endocrinology, and Surgery, School of Medicine, \\ East Carolina University, Greenville, North Carolina 27858-4354
}

\section{Abstract}

Insulin-like growth factor-I (IGF-I) in human hepatoma cells (HEP-G2) has, in addition to its effect on cell growth, shortterm metabolic effects acting through its own receptor. We have demonstrated that normal human hepatocytes, compared with HEP-G2 cells, have virtually no IGF-I binding sites. Because the rate of growth is the major difference between the hepatoma and the normal liver, we asked if normal liver might express IGF-I binding sites under physiologic growth conditions. Indeed, whereas adult rat hepatocytes have low IGF-I binding sites similar to those in human liver, hepatocytes from regenerating liver after $3 \mathrm{~d}$ subtotal hepatectomy have an approximately sixfold increase $(P<0.005)$ and those from fetal rat liver a $\sim 12$-fold increase $(P<0.005)$, to levels comparable to those in the HEP-G2 cells. The specificity of ${ }^{125}$ I IGF-I binding to its receptor was demonstrated by competition studies with monoclonal antibodies directed toward the IGF-I and the insulin receptors, with unlabeled IGF-I and insulin and by affinity labeling experiments. Thus, if IGF-I has any shortterm metabolic functions in the adult human liver, it is not through interaction with its own receptor. Autocrine regulation by IGF-I of liver growth appears possible since IGF-I binding sites are expressed under pathological and physiological conditions of growth. The mechanism that couples these two phenomena remains to be elucidated.

\section{Introduction}

Insulin and the type-I insulin-like growth factor (IGF-I) ${ }^{1}$ exhibit a similar spectrum of biological activities and have a high degree of sequence homology $(1,2)$. The primary event in the action of IGF-I on target cells, similar to that of insulin, appears to be the binding to specific receptors on the cell surface (2-4). The IGF-I receptor consists of heterotetrameric disulfide-linked subunits, the structure of which closely resembles that of the insulin receptor $(5,6)$. Given these similarities, it is not unexpected that insulin can react with the IGF-I receptor and that IGF-I can react with the insulin receptor (7). Each

Address reprint requests to Dr. Jose F. Caro, Department of Medicine, School of Medicine, East Carolina University, Greenville, NC 278344534.

Received for publication 11 July 1986 and in revised form 2 November 1987.

1. Abbreviations used in this paper: HEP-G2, hepatoma cells; IGF-I, insulin-like growth factor.

J. Clin. Invest.

(c) The American Society for Clinical Investigation, Inc.

0021-9738/88/04/0976/06 \$2.00

Volume 81, April 1988, 976-981 hormone can react with the other's binding sites, but with relatively reduced affinities (7). We have developed a method to isolate insulin-responsive human hepatocytes from 1-2 g intraoperative liver biopsy to study insulin action and resistance in man (8). Thus, it is imperative to study IGF-I binding and action in human liver to determine whether insulin-stimulated biological events are mediated through the insulin receptor or are due to IGF-I receptor occupation. This question is particularly relevant as it has recently been shown in the fetal rat hepatocytes that IGF-I was 20 times more potent than insulin in stimulating glycogen synthesis $(9,10)$. Similarly, in the human hepatoma cell line (HEP-G2), IGF-I stimulates glycogen synthesis, and insulin over $100 \mathrm{pM}$ appears to stimulate insulin action through interaction with the IGF-I binding sites (11).

\section{Methods}

Materials. Recombinant IGF-I was purchased from AMGen Biologicals, Thousand Oak, CA, and ${ }^{125} \mathrm{I}$ IGF-I $(2,000 \mathrm{Ci} / \mathrm{mmol})$ from Amersham Corp., Arlington Heights, IL. Crude collagenase (type IV, lot 25F6806) and deoxyribonuclease were obtained from Sigma Chemical Co., St. Louis, MO; dispase from Boehringer Mannheim Biochemicals, Indianapolis, IN; crude collagenase (4177 CLS II W2h202) and soybean trypsin inhibitor from Worthington Biomedical Corp., Freehold, NJ. Fraction $\mathrm{V}$ bovine serum albumin (BSA), obtained from Armour Pharmaceutical Company, Kankakee, IL, was purified by charcoal treatment (12). The following were gifts: monoclonal antibodies to the human IGF-I receptors ( $\alpha$ IR-I) from Dr. Steven Jacobs, Wellcome Research Laboratory, Research Triangle Park, NC, monoclonal antibodies to the human insulin receptors (51 B10) from Dr. Richard A. Roth, Stanford University School of Medicine, Stanford, CA, and HEP-G2 cell line from Dr. B. Knowles, Wistar Institute, Philadelphia, PA. Crystalline porcine insulin was a gift from Dr. Ronald Chouce of Eli Lilly and Co., Indianapolis, IN.

Isolated hepatocytes. Human hepatocytes were isolated as previously described (8). The donors were a 35-yr-old female with morbid obesity (weight $97 \mathrm{~kg}$, height $155 \mathrm{~cm}$ ) and without diabetes mellitus (fasting plasma glucose, $93 \mathrm{mg} / \mathrm{dl}$; fasting plasma insulin, $31 \mu \mathrm{U} / \mathrm{ml}$; peak plasma insulin during intravenous glucose tolerance test, 184 $\mu \mathrm{U} / \mathrm{ml}$; and $\mathrm{kg}$ rate $1.4 \% / \mathrm{min}$ glucose disappearance) and a 50 -yr-old female with morbid obesity $(95 \mathrm{~kg}$, height $165 \mathrm{~cm}$ ) and untreated non-insulin-dependent diabetes mellitus (fasting plasma glucose, 194 $\mathrm{mg} / \mathrm{dl}$; fasting plasma insulin, $38 \mu \mathrm{U} / \mathrm{ml}$; peak plasma insulin during intravenous glucose tolerance test, $46 \mu \mathrm{U} / \mathrm{ml}$; and $\mathrm{kg}$ rate $0.6 \% / \mathrm{min}$ glucose disappearance) undergoing an elective gastric bypass. The subjects underwent surgery in the morning after an overnight fast. No glucose was given intravenously before the liver biopsy. As soon as the abdomen was opened and explored to demonstrate no contraindication to the surgical procedure, a 1-2-g liver biopsy was obtained from the left lobe. Written consent was obtained from all patients after they were informed about the nature and potential risks of the study.

HEP-G2 cells were obtained from Dr. B. Knowles, Wistar Institute, Philadelphia, PA. The cells were cultured as described by Knowles et al. (13). Experiments were performed 3-4 d after plating, when the hepatocytes were still in the logarithmic phase of growth. 
Rat hepatocytes were isolated, as we have previously described (14), from adult normal male Sprague-Dawley rats, from regenerating liver after 1-4 d subtotal hepatectomy as described by Blachard et al. (15), and from $20 \mathrm{~d}$ gestation fetal Sprague-Dawley rats as described by Sinha et al. (16).

Liver plasma membranes. Liver plasma membranes were prepared from six male Sprague-Dawley rats on the third day after subtotal hepatectomy and their sham-operated, pair-fed controls, from three 20-d gestational fetal Sprague-Dawley rats, and from three human brain-dead organ donors who had no previous history of any metabolic disease. The liver tissue was homogenized in $1 \mathrm{mM} \mathrm{NaHCO}$ buffer, containing $0.5 \mathrm{mM} \mathrm{CaCl}_{2}$ (pH 7.5) as described by Ray (17), with the addition of $2 \mu \mathrm{M}$ leupeptin, $2 \mu \mathrm{M}$ pepstatin, $1 \mathrm{mM}$ penylmethylsulfonyl fluoride, $0.1 \mathrm{mg} / \mathrm{ml}$ bacitracin, and $1,000 \mathrm{U} / \mathrm{ml}$ aprotinine. The plasma membranes were isolated by the aqueous two-phase polymer method of Lesko et al. (18) with minor modifications (8). The membranes were suspended in $50 \mathrm{mM}$ Hepes buffer ( $\mathrm{pH} 7.4)$ and kept at $-70^{\circ} \mathrm{C}$ until they were used.

${ }^{125}$ I IGF-I binding. Hepatocytes $\left(\sim 1 \times 10^{6} \mathrm{cells} / \mathrm{ml}\right)$ were suspended in Hanks'-Hepes buffer ( $\mathrm{pH} 7.4$ ) containing $8 \mathrm{mM}$ glucose and $10 \mathrm{mg} / \mathrm{ml}$ BSA. HEP-G2 cells were either detached from the culture plates and suspended as described, or studied while adhered to $35-\mathrm{mm}$ plastic tissue culture dishes $\left(\sim 200 \mu \mathrm{g}\right.$ cell protein or $\sim 10^{6}$ cells per dish). Plasma membranes $(250 \mu \mathrm{g})$ were suspended in $250 \mu \mathrm{l}$ of KrebsRinger bicarbonate buffer ( $\mathrm{pH} 7.4$ ) containing $10 \mathrm{mg} / \mathrm{ml}$ BSA. To measure IGF-I binding, hepatocytes were incubated at $20^{\circ} \mathrm{C}$ with ${ }^{125} \mathrm{I}$ IGF-I $50 \mathrm{pM}$ in the presence of increasing concentrations of unlabeled hormone. After the desired duration of incubation, the cells or membranes were centrifuged, the incubation medium removed, and the pellets washed twice at $4^{\circ} \mathrm{C}$ with fresh medium. Nonspecific binding was determined by incubation in the presence of $50 \mathrm{nM}$ unlabeled IGF-I. Specific binding was calculated by subtracting nonspecific binding from total binding. An aliquot of the incubation medium was counted to determine the quantity of unbound IGF-I. To determine ${ }^{125}$ I IGF-I degradation, 10\% TCA was added to a portion of the incubation medium. The percentage of IGF-I degraded was calculated by dividing the total counts per minute precipitated by TCA and subtracting this from one.

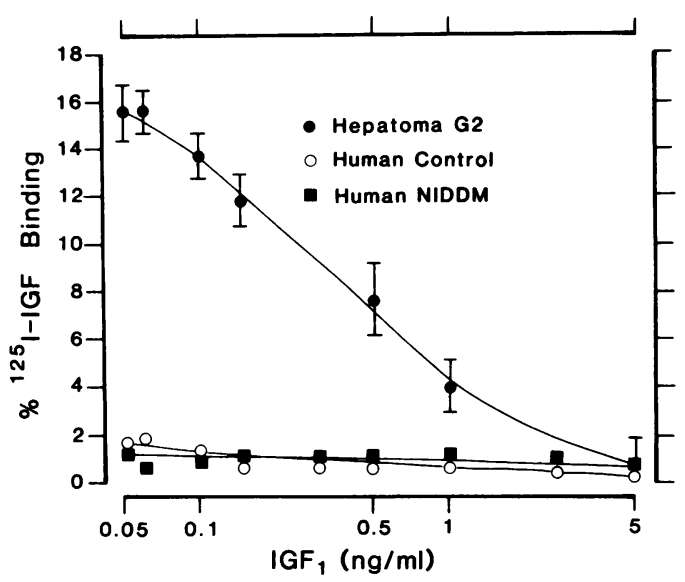

Figure 1. ${ }^{125}$ I IGF-I binding in HEP-G2 cells and isolated human hepatocytes. Cells $\left(\sim 1 \times 10^{6}\right.$ cells $\left./ \mathrm{ml}\right)$ were incubated with $50 \mathrm{pM}{ }^{125} \mathrm{I}$ IGF-I and increasing concentrations of unlabeled IGF-I for $120 \mathrm{~min}$ at $20^{\circ} \mathrm{C}$ in Hanks' Hepes buffer, pH 7.4, supplemented with $8 \mathrm{mM}$ glucose and $10 \mathrm{mg} / \mathrm{ml}$ BSA. Free ${ }^{125}$ I IGF-I was separated from bound by extensive washing with fresh incubation buffer at $4^{\circ} \mathrm{C}$. The data are expressed as percent specific binding per $1 \times 10^{6}$ cells. The data in HEP-G2 cells represent the mean \pm SEM of four separate determinations and those from humans with and without non-insulindependent diabetes mellitus (NIDDM) are the mean of triplicate samples.
Initial experiments were performed to determine optimal conditions under which to study IGF-I binding. At $20^{\circ} \mathrm{C}$, maximum IGF-I binding plateaued from 60 to $240 \mathrm{~min}$. Thus, the binding studies described in this report were performed at $20^{\circ} \mathrm{C}$ for 120 or $180 \mathrm{~min}$. Under these conditions, nonspecific binding and ligand degradation were $<20 \%$ of total IGF-I binding and free IGF-I in the incubation medium, respectively. Furthermore, IGF-I binding was linear over a range of $0.5-2 \times 10^{6}$ isolated hepatocytes and $100-250 \mu \mathrm{g}$ liver plasma membrane.

Affinity labeling of the IGF-I receptor. Following optimal ${ }^{125}$ I IGF-I binding in the absence and presence of unlabeled IGF-I $\left(1 \times 10^{-9} \mathrm{M}\right.$ to $\left.1 \times 10^{-6} \mathrm{M}\right)$ and unlabeled insulin $\left(1 \times 10^{-9} \mathrm{M}\right.$ to $\left.1 \times 10^{-6} \mathrm{M}\right)$ to liver plasma membranes as described in the preceding section, the ${ }^{125}$ I IGF-I receptor complex was covalently cross-linked with $0.5 \mathrm{mM}$ disuccinimidyl suberate for $10 \mathrm{~min}$ at $4^{\circ} \mathrm{C}$ by the method of Pilch and Czech (19). The reaction was stopped by adding $50 \mathrm{mM}$ Tris $\mathrm{HCl}(\mathrm{pH} \mathrm{7.0)}$ containing $1 \%$ SDS, 0.005 bromophenol blue, $2 \%$ glycerol, and $50 \mathrm{mM}$ dithiothreitol and boiling for $3 \mathrm{~min}$. Polyacrylamide gel electrophoresis was performed according to the method of Laemmli (20) in $7.5 \%$ polyacrylamide slab gels. Then the gels were stained, destained, dried, and autoradiographed with Kodak X-OMAT film using lightening plus-screen.

${ }^{125} \mathrm{I}$ insulin binding. ${ }^{125} \mathrm{I}$ insulin binding was performed in liver plasma membranes from the experimental groups as previously described (8).

Statistical analysis. Descriptive statistics (mean \pm SEM) and comparative statistics (analysis of variance and $t$ tests) were performed using a computerized program (Stat View, the graphic statistics for the Apple Macintosh).

\section{Results}

Fig. 1 shows the competitive binding studies of ${ }^{125}$ I IGF-I in HEP-G2 cells and human hepatocytes. This figure demonstrates that HEP-G2 cells, a minimal deviation human hepatoma, have specific ${ }^{125}$ I IGF binding sites as previously reported by Verspohl et al. (11). In contrast, Fig. 1 clearly shows that human hepatocytes have no detectable specific IGF-I binding. The human cells are morphologically intact with over $90 \%$ excluding trypan blue. These cells incorporate $\left[{ }^{14} \mathrm{C}\right]-$ leucine into proteins linearly for at least $2 \mathrm{~h}$; most importantly, we have previously shown that they respond to insulin in regard to lipid synthesis and amino acid transport, and have a similar number of insulin receptors as do rat hepatocytes (8). Fig. 2 further substantiates the specificity of IGF-I binding to HEP-G2 cells, as increasing concentrations of monoclonal antibodies to the IGF-I receptors compete in a dose-dependent manner with ${ }^{125}$ I IGF-I for the binding sites, whereas maximal

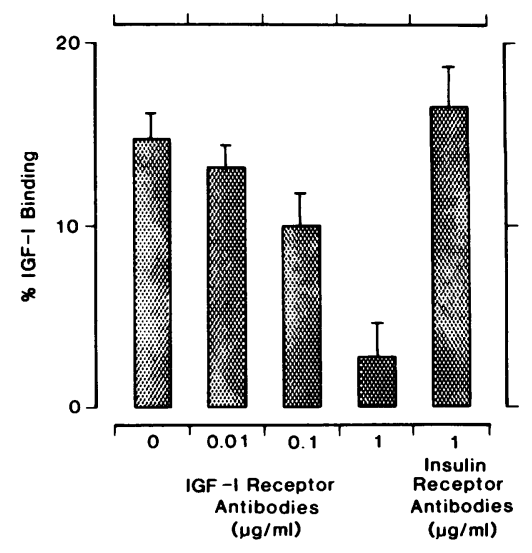

Figure 2. Effect of monoclonal antibodies to the IGF-I and insulin receptors on ${ }^{125}$ I IGF-I binding. ${ }^{125}$ I IGF-I binding was performed in the HEP-G2 cells, as described in the legend of Fig. 1, in the presence and absence of different concentrations of monoclonal antibodies to the IGF-I and insulin receptors. The data are the mean \pm SEM of four separate determinations. 
concentration of monoclonal antibodies to the insulin receptors had no effect.

Thus, a tissue from the same species under pathological conditions expresses a different amount of IGF-I binding sites. The major distinction between HEP-G2 cells and normal liver is the former's pathological growth rate and the fact that it has been maintained in culture. We then asked if normal liver could express IGF-I binding under physiological growth conditions. Fig. 3 attempts to answer this question. Freshly isolated hepatocytes from fetal rat liver have as much specific ${ }^{125} I$ IGF-I binding as did the HEP-G2 cells. ${ }^{125}$ IGF-I binding in fetal rat hepatocytes was statistically higher $(P<0.01-0.005)$ than the other experimental groups shown in Fig. 3. As previously shown by Massague and Czech in liver plasma membranes (7), freshly isolated hepatocytes from adult rat liver have extremely low, if any, IGF-I binding sites. Furthermore, IGF-I binding remained $<1 \%$ in primary cultures of adult rat hepatocytes for up to $48 \mathrm{~h}$. However, freshly isolated hepatocytes from regenerating adult rat liver after subtotal hepatectomy, have a significant increase in IGF-I binding that is maintained for up to $4 \mathrm{~d}$ when compared with normal adult hepatocytes (day $1-2, P<0.05$; day $3, P<0.005$; day $4 P$ $<0.025$ ). Insulin-like growth factor-I binding in liver after $3 \mathrm{~d}$ subtotal hepatectomy is higher than that from day $4(P$ $<0.025$ ), but it is not different from that from day $1-2$; likewise, day 1-2 is not statistically different from that from day 4 .

The advantages of using isolated hepatocytes is that they allow the selection of parenchymal cells. This is particularly true in the case of fetal liver, which contains a significant amount of hematopoetic tissue. A potential pitfall of this approach, however, is that the methodologies necessary to isolate human hepatocytes, adult rat hepatocytes, and fetal rat hepatocytes are significantly different, particularly since each requires a different type of collagenase. Thus, the changes observed could be due to differences in survival of the IGF-I receptor to a specific cell isolation procedure or collagenase type. To address this question, we prepared liver plasma membranes to study IGF-I binding, not from isolated hepatocytes, but from the liver. Furthermore, we introduced a shamoperated, control pair fed with the hepatectomized rats, since the increase in IGF-I binding in the regenerating liver could have been due to stress or nutritional factors.

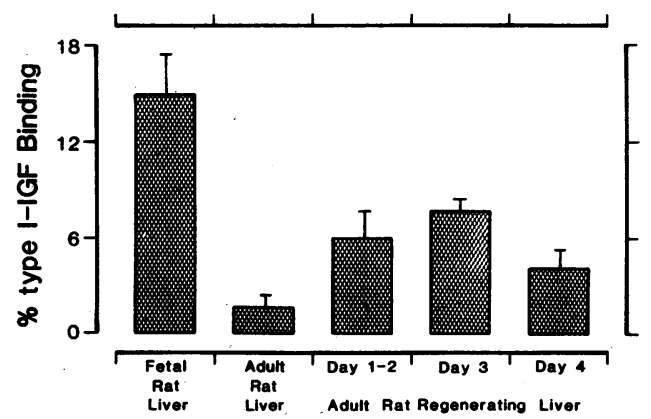

Figure 3. ${ }^{125}$ I IGF-I binding in adult, regenerating, and fetal rat hepatocytes. ${ }^{125}$ I IGF-I binding was performed in isolated hepatocytes derived from fetal and adult rats, and adult rats $1-2,3$, and $4 \mathrm{~d}$ after subtotal hepatectomy, as described in the legend of Fig. 1. The data represent the mean \pm SEM of three or five separate experiments.
Fig. 4 shows the data generated in liver plasma membranes. Fetal rat liver has statistically higher $(P<0.005)$ IGF-I binding when compared with liver from each of the other groups. Adult rat liver from $3 \mathrm{~d}$ after subtotal hepatectomy also has higher $(P<0.05)$ IGF-I binding than the respective sham-operated pair fed control. IGF-I binding in this adult rat control was no different from that found in adult human liver. The inset in Fig. 4 is a Scatchard plot of the data that suggests that the changes in IGF-I binding are mainly due to differences in the number of binding sites. However, since insulin and IGF-I cross-react with each others' receptor and it is known that there are differences in ${ }^{125} \mathrm{I}$ insulin binding among fetal rat liver (16), regenerating liver (21), and adult liver, ${ }^{125}$ I insulin binding was also measured in the same liver plasma membrane as shown in Fig. 5. It can be seen that the regenerating liver had approximately a half-fold increase in insulin binding when compared with the control; this difference was significant $(P<0.05)$ at the three lowest concentrations of insulin used, whereas the increase in IGF-I binding was approximately threefold (Fig. 4). Likewise, insulin binding in the human liver was similar to that in the rat liver, but IGF-I binding was extremely low. The increase in insulin binding in the fetal liver was approximately fourfold, whereas it was sixfold for IGF-I binding compared with the adult rat liver (Fig. 4). Thus, the changes in insulin binding observed cannot explain the data on IGF-I binding, particularly considering the limited cross-reactivity of insulin with the IGF-I receptor and of IGF-I with the insulin receptors (7). However, it should be recognized that, although to varying degrees, insulin and IGF-I binding are increased in regenerating and fetal rat liver. This is not surprising since both hormones exhibit a similar spectrum of biological activities and it is not a universal finding for other receptors (21).

To exclude the possibility that ${ }^{125}$ I IGF-I was interacting to a significant degree with the type II IGF receptor, we affinity labeled ${ }^{125}$ IGF-I to the plasma membranes. Figs. 6 and 7 dem-

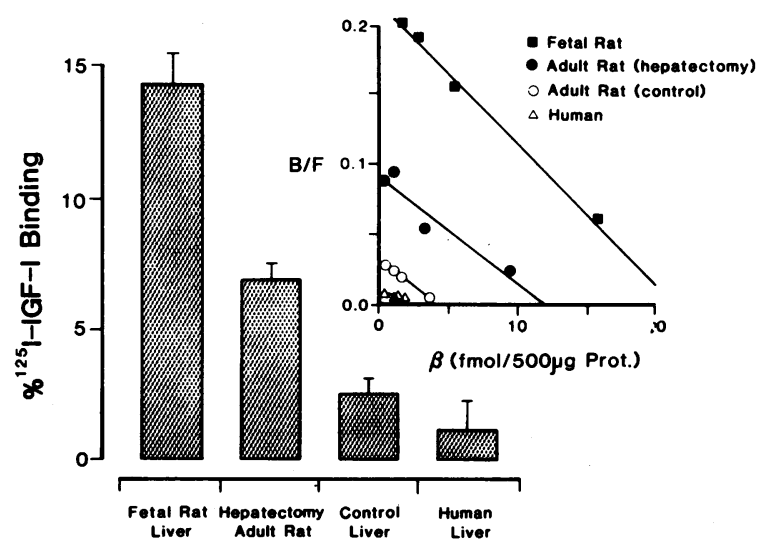

Figure 4. ${ }^{125}$ I IGF-I binding in fetal, regenerating, and adult rat and adult human liver plasma membranes. Liver plasma membranes ( $250 \mu \mathrm{g} /$ protein) were incubated in Krebs-Ringer bicarbonate buffer containing $10 \mathrm{mg} / \mathrm{ml} \mathrm{BSA}$ in the presence of ${ }^{125} \mathrm{I} \mathrm{IGF-I} \mathrm{(50} \mathrm{pM)} \mathrm{and}$ increasing concentrations of unlabeled IGF-I for $3 \mathrm{~h}$ at $20^{\circ} \mathrm{C}$. Then the membranes were separated from the medium by centrifugation, washed, and the radioactivity counted as described in the Methods section. The data represent the mean \pm SEM of percent specific ${ }^{125} I$ IGF-I binding at tracer concentration $(50 \mathrm{pM})$ from 3 or 4 separate experiments and a representative Scatchard plot of these data. 


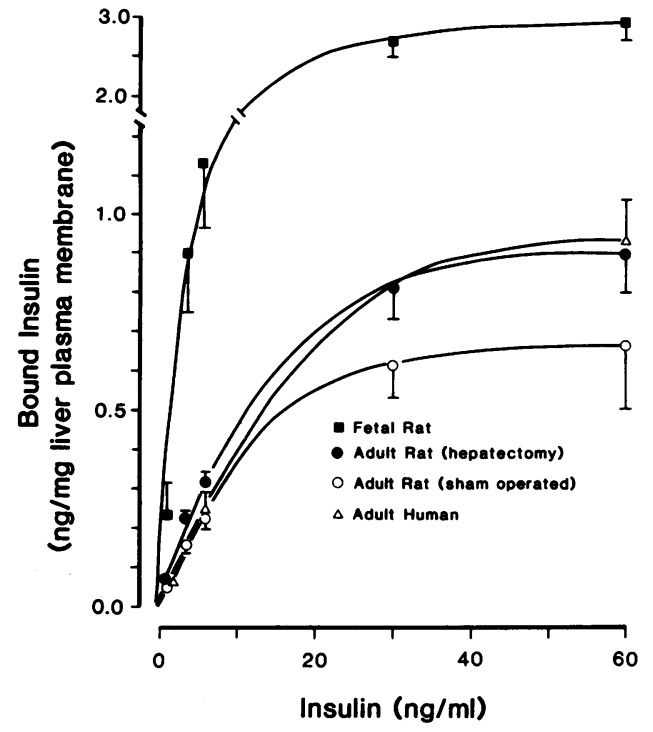

Figure 5. ${ }^{125} \mathrm{I}$ insulin binding to fetal, regenerating, and adult rat, and adult human liver plasma membranes. Liver plasma membranes were incubated in Krebs-Ringer bicarbonate buffer containing 10 $\mathrm{mg} / \mathrm{ml} \mathrm{BSA}$ in the presence of $1 \times 10^{-10} \mathrm{M}^{125} \mathrm{I}$ insulin and increasing concentrations of unlabeled insulin for $3 \mathrm{~h}$ at $20^{\circ} \mathrm{C}$. Then the membranes were separated from the medium by centrifugation, washed, and the radioactivity counted as described in Methods.

onstrate that incubation of liver plasma membranes from the regenerating and fetal rat liver, respectively, with ${ }^{125}$ I IGF and subsequent addition of disuccinimidyl suberate under reduced conditions labeled a protein of an approximate molecular mass of $130,000 \mathrm{D}$, which corresponded to the molecular mass of the $\alpha$-subunit of the IGF-I receptor. Since the $\alpha$-subunit of

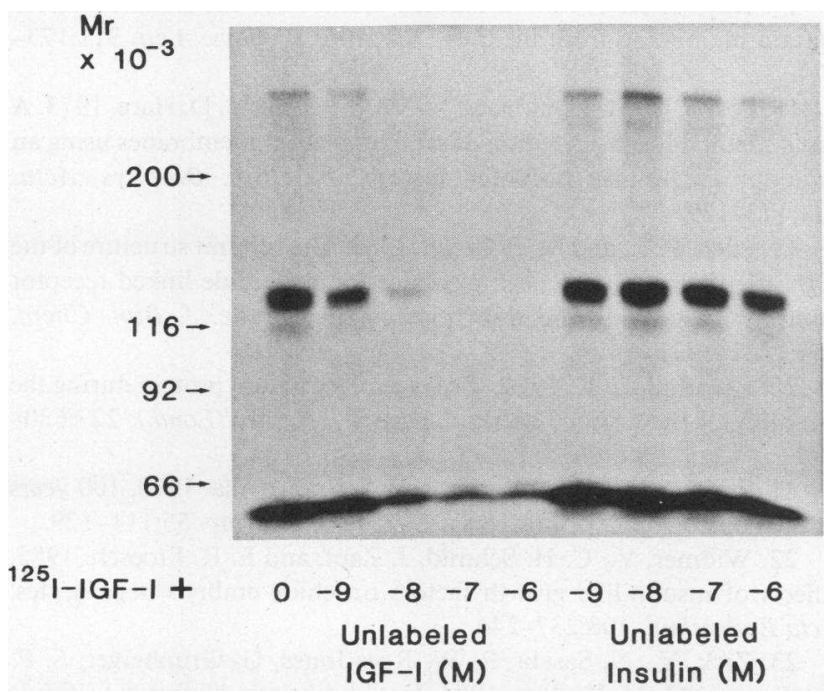

Figure 6. Autoradiogram of the $\alpha$-subunit composition of the reduced IGF-I receptors in fetal rat liver. ${ }^{125} \mathrm{I}$-IGF-I binding was performed in plasma membranes from fetal rat liver as described in the legend of Fig. 4 in the absence and presence of increasing concentrations of unlabeled IGF-I and insulin. The ${ }^{125}$ I IGF-I receptor complex was crosslinked with $0.5 \mathrm{mM}$ disuccinimidyl suberate, reduced with $50 \mathrm{mM}$ dithiothreitol, and subjected to SDS-PAGE followed by autoradiography.

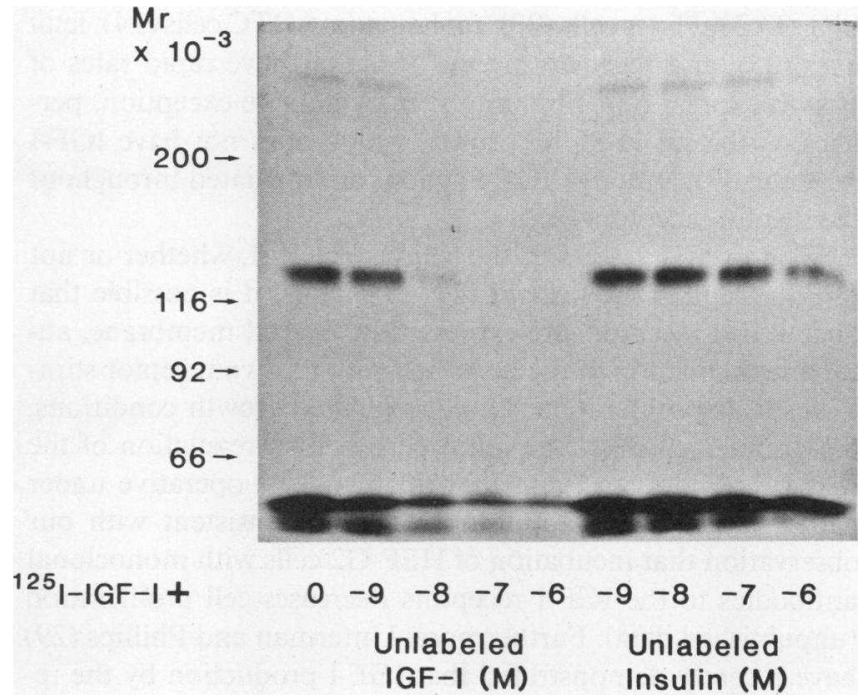

Figure 7. Autoradiogram of the $\alpha$-subunit composition of the reduced IGF-I receptors in 3-d regenerating rat liver. ${ }^{125}$ I-IGF-I binding was performed in plasma membranes from fetal rat liver as described in the legend of Fig. 4 in the absence and presence of increasing concentrations of unlabeled IGF-I and insulin. The ${ }^{125}$ I-IGF-I receptor complex was crosslinked with $0.5 \mathrm{mM}$ disuccinimidyl suberate, reduced with $50 \mathrm{mM}$ dithiothreitol, ànd subjected to SDS-PAGE followed by autoradiography.

the insulin receptor has a molecular mass similar to that of the IGF-I receptor, the same figure demonstrates that concentrations of unlabeled IGF-I between $1 \times 10^{-8} \mathrm{M}$ and $1 \times 10^{-7} \mathrm{M}$ totally displaced the radioactivity of these bands, whereas concentrations of unlabeled insulin as high as $1 \times 10^{-6} \mathrm{M}$ resulted in only minimal displacement, supporting the specificity of the IGF-I binding. Because of the low IGF-I binding in adult liver from human and rat, affinity labeling experiments could not be performed adequately. Finally, affinity labeling experiments of ${ }^{125} I$ insulin in the absence and presence of unlabeled IGF-I and insulin similarly showed the limited cross-reactivity between IGF-I and the insulin receptor in these experimental groups (data not shown).

\section{Discussion}

The main goal of this study was to begin to clarify the role of IGF-I in the metabolic regulation of the human liver. This effort was prompted by the observation of Verspohl et al. (11) that in HEP-G2 cells, a proposed model for the human liver, IGF-I had important short-term effects on metabolic functions acting through its own receptor. We have demonstrated in this study that the liver from adult humans has virtually no IGF-I binding sites. Thus, if IGF-I has any effect on the adult human liver, it is by interacting with other receptors or mediated by some other factors. Given this important difference between the transformed HEP-G2 cells and human liver, the use of HEP-G2 cells as a model of the human liver should be qualified.

It is well-demonstrated that IGF-I has potent long-term growth effect. In this regard, it is interesting that the adult human liver is devoid of IGF-I binding sites, similar to the livers of adult rat and mouse, as we and others have shown (7). In contrast, chick embryo hepatocytes (22), HEP-G2 cells (11), 
BRL 3A2 rat liver cells (23), rat hepatoma HTC cells (24), fetal liver (25), and regenerating rat liver that have rapid rates of growth express IGF-I binding sites. A notable exception, perhaps, is the rat H-35 hepatoma, which does not have IGF-I receptors (7), although IGF-I actions are mediated throughout the insulin receptors (26).

The liver is, however, the source of IGF-I, whether or not IGF-I receptors are present $(27,28)$. Thus, it is possible that once IGF-I receptors are expressed in the cell membrane, autocrine interaction of the hormone with its own receptor stimulates liver proliferation. Under regulated growth conditions, this initial step might be followed by down-regulation of the IGF-I receptors, an event that might not be operative under pathological growth conditions. This is consistent with our observation that incubation of HEP-G2 cells with monoclonal antibodies to the IGF-I receptors decreases cell proliferation (unpublished data). Furthermore, Unterman and Phillips (29) have recently demonstrated that IGF-I production by the regenerating rat liver is enhanced. In vitro studies also have shown that IGF-I stimulates the protein synthesis (30) and proliferation (31) of hepatocytes. Consistent with this notion is the finding that hypophysectomy retards hepatic regeneration (32), which can be improved by the administration of growth hormone.

IGF-I binding sites have been described in several human and nonhuman tissues $(2-7,11,22,33-40)$. The biological significance of the short-term effect of IGF-I on metabolic function in physiology and pathology in man is unclear at this time. If IGF-I plays any role, however, in the adult human liver, it is by interacting with other binding sites, because IGF-I binding is not present.

\section{Acknowledgments}

We thank Dr. Kirk Ways for the critical review of this manuscript; Dr. Steven Jacobs for antibodies to the IGF-I receptor; Dr. Richard Roth for antibodies to the insulin receptor; Dr. B. Knowles for the HEP-G2 cell line; Carolina Organ Procurement Agency for human liver; and Mrs. Diane Paramore of the Word Processing Center for its preparation.

This work was supported by grant P01 DK-36296-01 from the National Institutes of Health.

\section{References}

1. Rinderknecht, E., and R. E. Humbel. 1978. The amino-acid sequence of human insulin-like growth factor I and its structural homology with proinsulin. J. Biol. Chem. 253:2769-2776.

2. Zapf, J., E. Schoenle, and E. R. Froesch. 1978. Insulin-like growth factor I and II. Some biological actions and receptors binding characteristics of two purified constituents of non-suppressible insulin-like activity of human serum. Eur. J. Biochem. 87:285-296.

3. Fryklund, L., K. Uthne, and I. L. Sievertsson. 1974. Identification of two somatomedin A active polypeptides and in vivo effects of a somatomedin A concentrate. Biochem. Biophys. Res. Commun. 61:957-962.

4. Rechler, M. M., J. Zapf, S. P. Nissley, E. R. Froesch, A. C. Moses, J. M. Podskalny, E. F. Schilling, and R. E. Humbel. 1980. Interactions of insulin-like growth factors I and II and multiplicationstimulating activity with receptors and serum carrier proteins. Endocrinology. 107:1451-1459.

5. Massague, J., B. J. Guillette, and M. P. Czech. 1981. Affinity labelling of multiplication stimulating activity receptors in membranes from rat and human tissues. J. Biol. Chem. 256:2122-2125.
6. Kasuga, M., E. VanObberghen, S. P. Nissley, and M. M. Rechler. 1981. Demonstration of two subtypes of insulin-like growth factor receptors by affinity cross-linking. J. Biol. Chem. 256:5305-5308.

7. Massague, J., and M. P. Czech. 1982. The subunit structures of two distinct receptors for insulin-like growth factor I and II and their relationship to the insulin receptors. J. Biol. Chem. 257:5038-5045.

8. Caro, J. F., O. Ittoop, W. J. Pories, D. Meelheim, E. G. Flickinger, F. Thomas, M. Jenquin, J. F. Silverman, P. G. Khazanie, and M. K. Sinha. 1986. Studies on the mechanisms of insulin resistance in the liver from humans with non-insulin dependent diabetes: insulin action and binding in isolated hepatocytes, insulin receptors structure and kinase activity. J. Clin. Invest. 78:249-258.

9. Freemark, M., A. J. D'Ercole, and S. Hardwergen. 1985. Somatomedin-C stimulates glycogen synthesis in fetal rat hepatocytes. Endocrinology. 116:2578-2582.

10. Freemark, M. 1987. Epidermal growth factor stimulates glycogen synthesis in fetal rat hepatocytes: comparison with the glycogenic effects of insulin-like growth factor I and insulin. Endocrinology. 119:522-526.

11. Verspohl, E. J., R. A. Roth, R. Vijneri, and I. D. Goldfine. 1984. Dual regulation of glycogen metabolism by insulin and insulinlike growth factors in humans' hepatoma cells (HEP-G2). Analysis with an anti-receptor monoclonal antibody. J. Clin. Invest. 74:14361443.

12. Chen, R. F. 1967. Removal of fatty acids from serum albumin by charcoal treatment. J. Biol. Chem. 242:173-181.

13. Knowles, B. B., C. C. Howe, and D. P. Aden. 1980. Human hepatocellular carcinous cell line secretes the major plasma proteins with hepatitis B surface antigen. Science (Wash. DC). 209:497-498.

14. Caro, J. F., and S. Lanza-Jacoby. 1983. Insulin resistance in uremia. Characterization of lipid metabolism in freshly isolated and primary cultures of hepatocytes from chronic uremic rats. J. Clin. Invest. 72:882-892.

15. Blachard, W. G., P. S. Guzelian, and M. E. Small. 1978. Down regulation of insulin receptors in primary cultures of adult rat hepatocytes in monolayer. Endocrinology. 103:548-553.

16. Sinha, M. K., J. D. Miller, M. A. Sperling, F. J. Suchy, and S. Ganguli. 1984. Possible disassociation between insulin binding and insulin action in isolated fetal rat hepatocytes. Diabetes. 33:864-871.

17. Ray, T. K. 1970. A modified method for the isolation at the plasma membrane from rat liver. Biochim. Biophys. Acta. 311:173179.

18. Lesko, L., M. Donlon, G. V. Marinetti, and J. D. Hare. 1973. A rapid method for the isolation of rat liver plasma membranes using an aqueous two-phase polymer system. Biochim. Biophys. Acta. 311:173-179.

19. Pilch, P. F., and M. P. Czech. 1980. The subunit structure of the high affinity insulin receptor: evidence for a disulfide linked receptor complex in fat cell and liver plasma membrane. J. Biol. Chem. 255:1722-1731.

20. Laemmli, U. K. 1970. Cleavage of structural protein during the assembly of the head of bacteriophage $\mathrm{T}_{4}$. Nature (Lond.). 227:680685.

21. Starzl, T. E., K. A. Porter, and A. Francavilla. 1978. 100 years of the hepatotrophic controversy. Ciba Found. Symp. 55:111-129.

22. Widmer, V., C. H. Schmid, J. Zapf, and E. R. Froesch. 1985. Effects of insulin-like growth factors on chick embryo hepatocytes. Acta Endocrinol. 108:237-244.

23. Zick, Y., N. Sasaki, R. W. Rees-Jones, G. Grunberger, S. P. Nissley, and M. M. Rechler. 1984. Insulin-like growth factor-I (IGF-I) stimulates tyrosine kinase activity in purified receptors from a rat liver cell line. Biochem. Biophys. Res. Commun. 119:6-13.

24. Heaton, J. H., V. L. Krett, J. M. Alvarez, T. D. Gelehrter, J. A. Romanus, and M. M. Rechler. 1984. Insulin regulation of insulin-like growth factor action in rat hepatocyte cells. J. Biol. Chem. 259:23962402.

25. Chernauseh, S. D., D. C. Beach, W. Banach, and M. A. Sperling. 1987. Characteristics of hepatic receptors for somatomedin-C/in- 
sulin-like growth factor I and insulin in the developing human. J. Clin. Endocrinol. \& Metab. 64:737-743.

26. Krett, N. L., J. H. Heaton, and T. D. Gelehrter. 1987. Mediation of insulin-like growth factor actions by the insulin receptor in H-35 rat hepatoma cells. Endocrinology. 120:483-490.

27. Zapf, J., E. R. Froesch, and R. E. Humbel. 1981. The insulinlike growth factors (IGF) of human serum: chemical and biological characterization and aspects of their possible physiological role. Curr. Top. Cell. Regul. 12:257-309.

28. Van Wyk, J. J., L. E. Underwood, and R. L. Hintz. 1974. The somatomedins: a family of insulin-like peptides under growth hormone control. Recent Prog. Horm. Res. 30:259-318.

29. Unterman, T. G., and L. S. Phillips. 1986. Circulating somatomedin activity during hepatic regeneration. Endocrinology. 119:185192.

30. Baxter, R. C., and J. R. Turtle. 1978. Stimulation in isolated hepatocytes by somatomedin. Metab. Clin. Exp. 27:503-508.

31. Koch, K. S., P. Shapiro, H. Shelly, and H. L. Leffert. 1982. Rat hepatocytes proliferation is stimulated by insulin-like peptides in defined medium. Biochem. Biophys. Res. Commun. 109:1054-1057.

32. Uthne, K., and T. Uthne. 1979. Influence of liver resection and regeneration on somatomedin activity in sera from normal and hypophysectomized rats. Acta Endocrinol. (Copenh.). 71:255-261.

33. Franh, H. J. L., W. M. Pardridge, W. L. Morris, R. G. Rosenfeld, and T. B. Choi. 1986. Binding and internalization of insulin and insulin-like growth factors by isolated brain microvessels. Diabetes. 35:654-661.
34. Megyesi, K., C. R. Kahn, J. Roth, D. M. Neville, S. P. Nissley, R. E. Humbel, and R. Froesch. 1975. The NSILA-s receptor in liver plasma membranes. J. Biol. Chem. 250:8990-8996.

35. Lee, P. D. K., R. G. Rosenfeld, R. L. Hintz, and S. D. Smith. 1986. Characterization of insulin, insulin-like growth factors I and II, and growth hormone receptors on human leukemia lymphoblasts. $J$. Clin. Endocrinol. \& Metab. 62:28-35.

36. Izumi, T., M. Kasuga, T. Kadowaki, N. Hizuka, F. Takaku, and Y. Akanuma. 1986. Characteristics of human erythrocyte insulinlike growth factor I receptors. J. Clin. Endocrinol. \& Metab. 62:12061212.

37. Flier, J. S., P. Usher, and A. C. Moses. 1986. Monoclonal antibody to the type I insulin-like growth factor (IGF-I) receptor blocks IGF-I receptor-mediated DNA synthesis: clarification of the mutogenic mechanisms of IGF-I and insulin in human skin fibroblasts. Proc. Natl. Acad. Sci. USA. 83:664-668.

38. Schwartz, J., C. M. Foster, and M. S. Satin. 1985. Growth hormone and insulin-like growth factors I and II produce distinct alterations in glucose metabolism in 3T3-F442A adipocytes. Proc. Natl. Acad. Sci. USA. 82:8724-8728.

39. Beguinot, F., C. R. Kahn, A. C. Moses, and R. J. Smith. 1985. Distinct biologically active receptors for insulin, insulin-like growth factor I and insulin-like growth factor II in cultured skeletal muscle cells. J. Biol. Chem. 260:15892-15989.

40. Poretsky, L., F. Grigorescu, M. Seibel, A. C. Moses, and J. S. Flier. 1985. Distinction and characterization of insulin and insulin-like growth factor I receptors in normal human ovary. J. Clin. Endocrinol. \& Metab. 61:728-734. 